\title{
The Determinants of the Occupational Diseases in Al-Nasiriyah Province at 2018
}

\author{
Majeed MohanThajeel Al-Hamami', Mulim Nahi², Ali A. Saadoon ${ }^{2}$, Safaa Kudhaier Abbas ${ }^{3}$ \\ ${ }^{1}$ Department of Internal Medicine, College of medicine / University of Thi- Qar, Iraq, ${ }^{2}$ Department of Family and \\ Community Medicine, College of medicine / University of Thi- Qar, Iraq, ${ }^{3}$ Health Decorticate of Thi-Qar, Iraq
}

\begin{abstract}
Background: The occupational diseases are the major epidemic problem in the field of public health in developing countries (WHO(.It is do not arise haphazardly among the workers, but happens only when an appropriate accumulation of determinants or risk factors. .

The Aims of the study were to assess the general workers $>$ health. and to explore the determinants) risk factors and causes (of the occupational disease within selected fields of work in Al-Nasiriyah province at 2018.

Method and material: An analytical cross-sectional study was conducted in Al Nasiriyah thermal electrical plant, cable plant and oil refinery in the Al Nasiriyah -province at 2018. A multistage cluster sampling method was conducted to recruit )369 (workers. The data gathered by survey questionnaire and processed by statistical analysis.
\end{abstract}

Result: The extent of occupational exposure was about 89.7\% with exposed to the non-exposed ratio) 8.7:1 (. About $\mathbf{3 1 . 8} \%$ of the workers exposed to the respiratory hazards (thinner, PVF, PVC, Ammonia and acoustic agents). About exposed cases with RADS (41 cases) had about )0.000(P. value. The Noise exposure had $71.5 \%$ )264(. of the workers The exposed cases with NIHL (23 cases) had about )0.015(. P. value. An odds ratio of the occupationally exposed to the non-exposed worker was equal to 19.1. Binary Logistic Regression was done to adjust the confounder factors for systematically classified occupational diseases which augments the significance of the association for occupational exposure, age and work duration.

Recommendations: Introducing the speciality of the occupational physician in primary health care with preparing for the establishment of the Thi-Qar occupational medical centre to promote the optimal occupational medical care.

Keywords: Determinants, Occupational diseases, Occupational exposure, Injury, Al-Nasiriyah.

\section{Introduction}

11,2] Work may have an annoying or hazardous exposure.

${ }^{[1,2]}$ Each occupation has its hazard which is the potential harm workplace substances ${ }^{[3,4]}$ These are including chemical, physical, biological and ergonomic hazards ${ }^{[5,6]}$ The risk for the occupational disease andword related disease was covered by two aspects First: General risk for the chronic and workplace-related diseases, Second: Specific risk for occupational diseases. The dose, frequency and duration of the occupational exposure determine the extent of the work- related and occupational diseases ${ }^{[8]}$ This trigger a workplace health risk by acute and chronic (accumulated) effects which lead to the emergence of occupational diseases [9] for example, Asbestosis from the asbestos exposure. Currently occupational health services coverage account about $\mathbf{2 4 . 8 \%}$ only of the workers worldwide including the Health surveillance, occupational risk prevention, first aid ${ }_{\hat{p} 10]}$ dvising and training programs in workplace safety. ${ }^{[10]}$ The negative influences of the workplace environment on worker health can be summarized in the form of the exacerbation of current illnesses, certain occupational diseases causality, undesirable influences on productivity. ${ }^{[11]}$ The workershave In AL Nasiriyah City and as an inductive look for the medical occupational reality, some points could have been 
being formulated: 1) There is no available in integral, considerations about the nature, extent and It was planned to highlight occupational diseases in the three locally effective, vital, hazardous with 24 hours task and richly in manpower enterprises. These are including: Electrical generation employees operate in the risky workplace and exposure to live power, magnetic field, Chemical exhaust hard official duties in the potentially hazardous workplace ${ }^{[12]}$ National Institute for Occupational Health NIOH and WHO 19, [13] are building a Global Plan of Action on Workers' Health GPAWH which involve

1. Notifying and Registry of occupational risk factors and diseases and

2. Estimating capacities for the occupational burden of diseases.

3. Diagnosis improvement.

4. And categorized it as preventable diseases.

Hazard identification and risk assessments were needing to be identified ${ }^{[9]}$ Preventive measures have other important entity to eliminate or reduce the emerging of the occupational diseases. ${ }^{[14]}$ Occupational health and occupational hygiene have an overlapped role in risk assessment ${ }^{[15]}$ ILO recommended that there is a causal relationship with a specific exposure or work process in a specific work environment concerned with an epidemiological determinants and frequency which exceeds within the rest of the population. ${ }^{[16]}$ In Iraq and other developing countries, the rate of the occupational illnesses and accidents are assumed to be greater than that in developed countries. However, the described rates in these countries are much lower than the existent number ${ }^{[17]}$ determinants of the work and workrelated disease in Al Nasiriyah industrial institutes. 2) The poverty of the medical occupational services. and physical waste to can lead to serious illnesses, injury or death. ${ }^{[18]}$ It is worth noting that petroleum refining and distribution perceived to be respiratory, MSK, CNS hazardous effects where complex hydrocarbon compounds are separated and conversion.

Cable industry dealing with adversely health impact compounds include (lead, cadmium, halogenated flameretardants. ${ }^{[20]}$ Also, Aluminium industry has a toxic effect on the respiratory tract as pulmonary fibrosis, asthma and chronic bronchitis with acute related symptoms were significantly more prevalent among the aluminium exposed worker ${ }^{[21]}$.

By academic standpoint, it is necessary to conduct an observational descriptive analytical study to be a step in the way of answering the questions of this problem. There are many labour enterprises in this city. The largest and most vital institutes are selected to be as a paradigm of the accessible institutionalized population. To investigate a snapshot study about the extent and determinants of the work and workplace- related diseases. These enterprises are:

- UR State Company

- Al-NasiriyaThermal Power Station.

- Thi- Qar Oil Refinery. Preventive occupational measures

Primary prevention is achieved by the methods of exposure reduction of hazardous substances to decrease the risk of disease.

Secondary prevention This involves the occupational disease surveillance achieved by

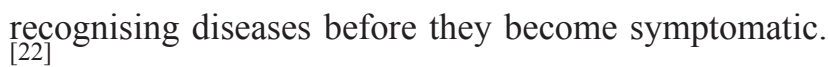

Tertiary Prevention: This achieves by limiting the discomfort or symptoms, reduce body injury to the and boost the operational capacity.

\section{Methodology}

\section{Profile of Study Area}

- Al-Nasiriya city The study was conducted in Al- Nasiriyah city - the capital of Thi-Qar governoratewhich is the 4th most inhabited city in Iraq ${ }^{[15]}$. It is located along the lines of the Euphrates River, about )370 $\mathbf{k m}$ (southeast of Baghdad, close to an ancient city of Ur. According to the Iraqi central statistic organization, there is about )2,040,126( calculated population in $\mathbf{2 0 1 4}{ }^{[16]}$. Al Nasiriya City population estimated in $\mathbf{2 0 1 7}$ )793472 individuals( by Thi-Qar Statistics Directorate with a male to female ratio $1: 1$ approxemaitly ${ }^{[17]}$

- UR State Company. Ur Company is one of the companies of the Ministry of Industry and Minerals of Iraq It is located in the southeast of Nasiriyah city. The company was established in 1988. Specializes in the production of all types of cables, electrical and telephone wires in addition to aluminium products. It includes 17 organizational unit contain about $\mathbf{( 3 1 0 8 )}$ workers. 
- Al-Nasiriya Thermal Power Station. It is one of the formations of the Iraqi Ministry of Electricity. It had been founded in 1979. The plant consists of four generating units. The first and second units produce 350 MW while the third produces $175 \mathrm{MW}$ after completion of maintenance and the fourth 165 MW. The station operates a hot steam system to move the giant turbines. It is located on the right bank of the Euphrates in the west AL- Nasiriyah. It has more than )1,600( members working in the alternating system ${ }^{[25]}$

Thi- Qar Oil Refinery One of the formations of the Ministry of Oil, South Refineries Company located south of the AL- Nasiriyah city of. It is receiving a crude oil for refining and contains several units for the separation, isolation and storage of oil products it contain about) $\mathbf{1 3 3 7}$ (workers. ${ }^{[24]}$

Population of study: Field and office employees in the enterprises of the interest who responded to participate in the study. About )6200( of the candidate employees were involved and identify in the sampling frame. Study Design: An analytical cross-sectional study for exploring the extent occupational diseases which was conducted in Al Nasiriyah thermal electrical plant, cable plant and oil refinery in the - City from the 1st of November 2017 to the 1st of the November 2018 .

Sample size: HSE statistics report )2017) ${ }^{[18,19]}$ for various work-related ill health was accredited and the highest prevalence rate $\mathbf{4 0 \%}$ ( was obtained for extracting the sample size according to the Dobson's formula ${ }^{[20]}$ to recruit) $\mathbf{3 6 9}$ (workers.

Data Analysis carried out by SPSS version $25^{\text {[21] }}$

\section{Results}

Total extent of the occupational exposure was $89.7 \%$ of the workers with exposed to non- exposed ratio about 8.7:1. The highest extent of the occupational exposure was $98.8 \%$ within (18-30 years) age group. Males and female>s percentages of occupational exposure were $89.1 \%$ and $10.9 \%$ respectively with. The married accounted for the highest extent $92.4 \%$ of the exposed workers

Occupational respiratory risk factors Respiratory irritant chemicals consisted of (thinner, PVF, PVC, Ammonia and acoustic agents had a percentage of 31.8 $\%$ of the totals ) 118 (. Exposed with RADS had P. value ) 0.000 (with the 32.206 ) Fisher Exact test value41 ).Figure 1.

\section{Occupational hearing loss risk factors}

The Noise exposure had a percentage of $71.5 \%$ of the totals )264(. The diseased workers with NIHL were accounting 5.1\%)19 cases(of the total and non-diseased were accounting for $94.9 \%$ (350 cases). Exposed cases with NIHL )23( had a P. value )0.015( with the 10.173 ) Fisher Exact test value. Figure2. Noise percentage was the highest frequency among the occupational exposure with $71.5 \%$ ) 264( workers. Most of them presented with a daily pattern of frequency one or two times per day. Ammonia and the acoustic agent had about )22.8\%( exposure percentage with )84( workers for both with only daily frequency. The lesser exposure percentage was for the welding fumes and dust with $1.9 \%$ and $1.1 \%$ respectively. Table 2 .

Table 1 Occupational exposure Distribution According to the demographic information of the workers in AL -Nasiriyah Province at 2018

\begin{tabular}{|c|c|c|c|c|c|c|c|}
\hline \multirow{2}{*}{\multicolumn{2}{|c|}{ Exposed }} & \multicolumn{6}{|c|}{ Occupational Exposure } \\
\hline & & \multicolumn{2}{|c|}{ Non- Exp. } & \multicolumn{2}{|l|}{ Total } & \multirow[b]{2}{*}{49} & \multirow[b]{2}{*}{$13.3 \%$} \\
\hline \multirow{5}{*}{ Age } & $18-30$ years & 46 & $13.9 \%$ & 3 & $7.9 \%$ & & \\
\hline & $31-40$ years & 66 & $19.9 \%$ & 6 & $15.8 \%$ & 72 & $19.5 \%$ \\
\hline & $41-50$ years & 150 & $45.3 \%$ & 22 & $57.9 \%$ & 172 & $46.6 \%$ \\
\hline & $51-60$ years & 58 & $17.5 \%$ & 6 & $15.8 \%$ & 64 & $17.4 \%$ \\
\hline & $\begin{array}{l}\text { More than } 60 \\
\text { years }\end{array}$ & 11 & $3.4 \%$ & 1 & $2.6 \%$ & 12 & $3.2 \%$ \\
\hline \multirow{2}{*}{$\begin{array}{l}\text { Sex } \\
\text { Female }\end{array}$} & Male & 295 & $89.1 \%$ & 13 & $34.3 \%$ & 308 & $83.4 \%$ \\
\hline & 36 & $10.9 \%$ & 25 & $65.7 \%$ & 61 & $16.6 \%$ & \\
\hline
\end{tabular}


Cont... Table 1 Occupational exposure Distribution According to the demographic information of the workers in AL -Nasiriyah Province at 2018

\begin{tabular}{|c|c|c|c|c|c|c|c|}
\hline \multirow[b]{2}{*}{ Marital Status } & Single & 24 & $7.3 \%$ & 2 & $5.3 \%$ & 26 & $7.1 \%$ \\
\hline & 306 & $92.4 \%$ & 33 & $86.8 \%$ & 339 & $91.9 \%$ & \\
\hline \multirow{2}{*}{\multicolumn{2}{|c|}{$\begin{array}{l}\text { Married } \\
\text { Divorced } \\
\text { Widowed }\end{array}$}} & $0 \%$ & 2 & $5.3 \%$ & 2 & $0.5 \%$ & \\
\hline & & $0.3 \%$ & 1 & $2.6 \%$ & 2 & $0.5 \%$ & \\
\hline \multirow{3}{*}{$\begin{array}{l}\text { Residency } \\
\text { Semi- urban } \\
\text { Rural }\end{array}$} & urban & 231 & $69.7 \%$ & 20 & $52.6 \%$ & 251 & $68 \%$ \\
\hline & 60 & $18.2 \%$ & 15 & $39.5 \%$ & 75 & $20.4 \%$ & \\
\hline & 40 & $12.1 \%$ & 3 & $7.9 \%$ & 43 & $11.6 \%$ & \\
\hline \multirow{5}{*}{$\begin{array}{l}\text { Level of the } \\
\text { Education }\end{array}$} & Illiterate & 4 & $1.2 \%$ & 0 & $0 \%$ & 4 & $1.2 \%$ \\
\hline & Primary & 45 & $13.7 \%$ & 6 & $15.8 \%$ & 51 & $13.9 \%$ \\
\hline & Intermediate & 8 & $2.4 \%$ & 3 & $7.9 \%$ & 11 & $2.9 \%$ \\
\hline & Secondary & 136 & $41.1 \%$ & 13 & $34.2 \%$ & 149 & $40.3 \%$ \\
\hline & Tertiary & 138 & $41.6 \%$ & 16 & $42.1 \%$ & 154 & $41.7 \%$ \\
\hline \multicolumn{2}{|l|}{ Total } & 331 & $89.7 \%$ & 38 & $10.3 \%$ & & 369 \\
\hline
\end{tabular}

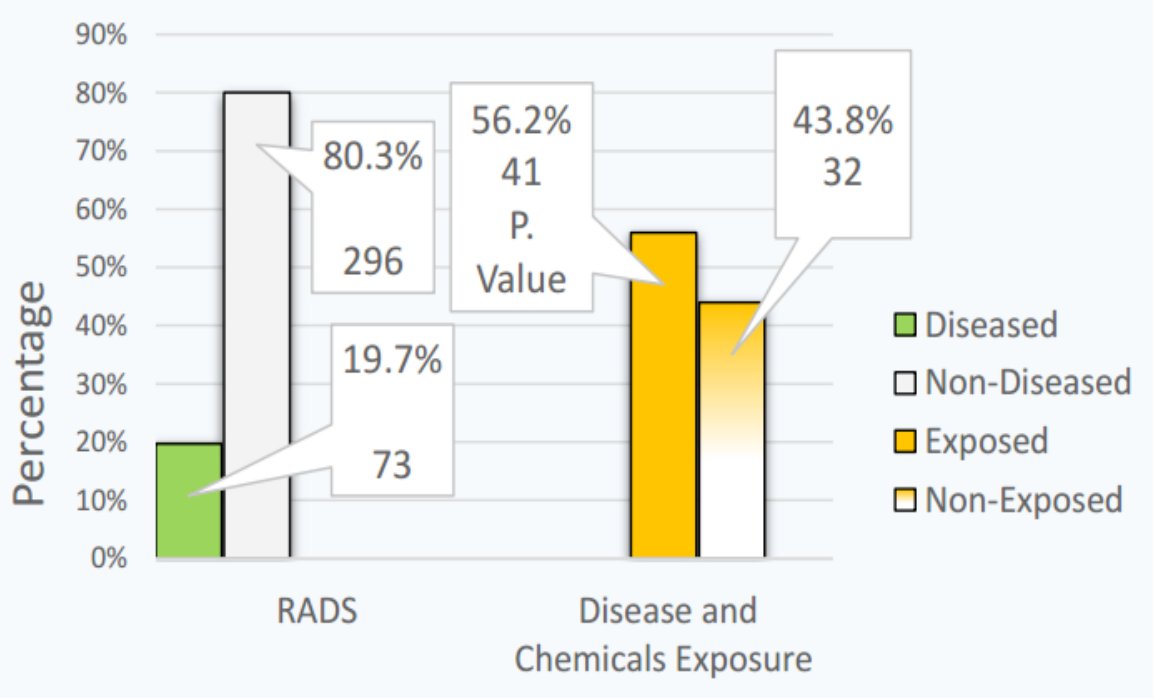

Figure 1. Association between the RADS and Respiratory Irritant Chemicals Exposure among the workers in AL-Nasiriyah city at 2018

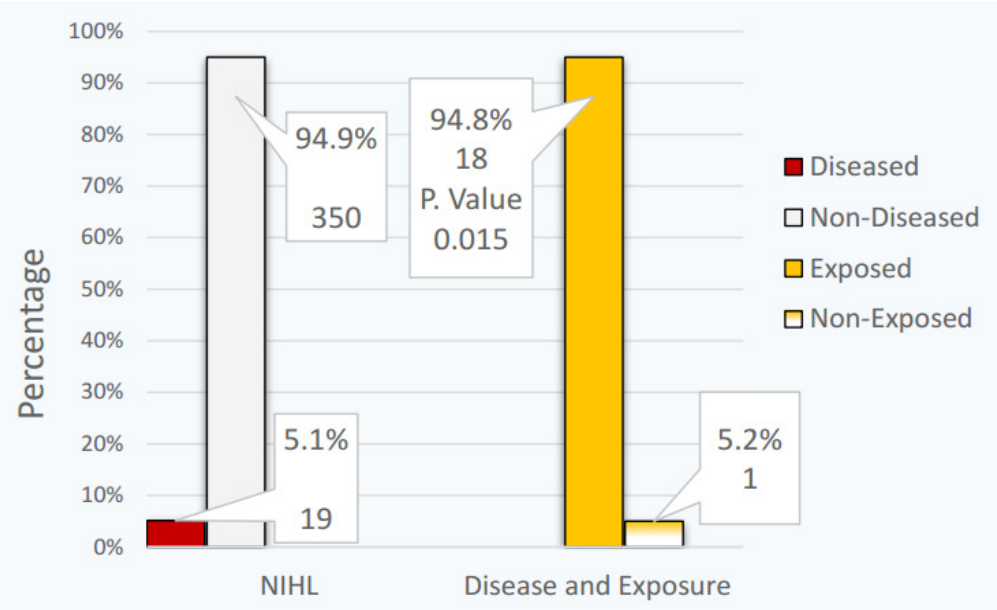

Figure 2. Association between the NIHL with the Noise Expossure amongthe workers in AL-Nasiriyha city at 2018 
Table 2 Occupational exposure and frequency in the institutes of the interest in Al-Nasiriyah Province at 2018

\begin{tabular}{|c|c|c|c|c|c|c|}
\hline \multirow[b]{2}{*}{ Substances } & \multicolumn{6}{|c|}{ Exposure Frequency } \\
\hline & 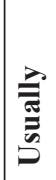 & 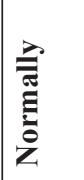 & ฮँ & 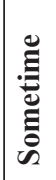 & 饲 & $\begin{array}{l}\overrightarrow{\bar{E}} \\
\dot{\Xi} \\
\dot{\Xi}\end{array}$ \\
\hline Noise & 1 & 247 & 15 & 1 & 264 & $71.5 \%$ \\
\hline Heat & & 224 & 10 & 2 & 235 & $64 \%$ \\
\hline Gases & & 138 & 5 & 1 & 138 & $39 \% 1$ \\
\hline Heavy Lifting & & 103 & 9 & & 112 & $30.4 \%$ \\
\hline Ammonia & & 84 & & & 84 & $22.8 \%$ \\
\hline Acoustic Agents & & 84 & & & 84 & $22.8 \%$ \\
\hline Unstable posture & 8 & 66 & 1 & 1 & 76 & $20.6 \%$ \\
\hline Chemicals & & 56 & & & 56 & $12.2 \%$ \\
\hline Exhaust Combustion & & 43 & & & 43 & $1.7 \% 1$ \\
\hline Polyvinylchloride & & 28 & 11 & 3 & 42 & $11.4 \%$ \\
\hline Benzene & & 99 & 1 & & 40 & $24.4 \%$ \\
\hline Thinner & 2 & 25 & 7 & & 34 & $9.2 \%$ \\
\hline Polyvinyl Formaldehyde & 2 & 24 & 7 & & 33 & $8.9 \%$ \\
\hline cooling oil Vapor & & 22 & 6 & & 28 & $7.6 \%$ \\
\hline Non-Ionic Rad & & 20 & & & 19 & $5.4 \%$ \\
\hline Aluminum Vapor & & 15 & & & 15 & $4.1 \%$ \\
\hline Sawdust & & 7 & 1 & & 8 & $2.2 \%$ \\
\hline Welding Fumes & & 4 & 2 & 1 & 4 & $1.9 \%$ \\
\hline Dust & & 1 & 2 & 1 & 4 & $1.1 \%$ \\
\hline Repetitive movement & & 3 & 1 & & 4 & $1.1 \%$ \\
\hline
\end{tabular}

\section{Discussion}

The highly extent $\mathbf{8 9 . 7 \% ( o f ~ t h e ~ o c c u p a t i o n a l ~}$ exposure implies poor local health protective strategy ${ }^{[7]}$ with more expected adverse accumulative effect among $\mathbf{4 5 . 3 \%}$ of the $) \mathbf{4 1 - 5 0} \mathrm{ys}$ ( age group of the sampled workers by this study. The hazards exposure passing through a latent period of years to emerge the related disease symptoms ${ }^{[31]}$, this study cannot be evaluated it due to the )cross- sectional( design.

\section{Occupational respiratory risk factors}

There is a very highly significant statistical correlation )P. value 0.000 ( between the respiratory irritant exposure with RADS that pushed toward reject the null hypotheses with positive relation by)32.206( Fisher Exact. There is low petroleum-derived hydrocarbons associated with RADS and Nasal symptoms by the study of Sekkal, Samira, Haddam, Nahida, Scheers, Hans, Poels, Katrien L, Bouhacina, Linda, Nawrot, Tim S, Veulemans, Hendrik A, Taleb, Abdesselam, Nemery, Benoit 2014( ${ }^{[32]}$

\section{Occupational hearing loss risk factors}

About 5.1\%)19(cases of the partial reducing hearing ability who diagnosed by otolaryngologist diagnosis via the audiogram. About)16(cases of them had their chronic occupational noise exposure with highly significant 
statistical association P. value (0.015) that rejects the null hypotheses with a strong positive relation (Fisher Exact 10.173. About) $42 \%$ ( of the workers with the noise exposure, all of those with the more than )10(years> noise exposure were presenting with NIHL by )Feder, Katya, Michaud, David, McNamee, James(while in this study, about 66\% )200( of the workers with the noise exposure, only $9 \%$ of them of the more than 10 years $>$ noise exposure were presenting with NIHL The highly noise exposure $89.7 \%$ of the sampled workers implies hazards impact increasing with poverty of ear protective strategy. Noise has adverse hearing psychological cardiac and vascular impacts.

\section{Recommendations}

1. Introducing the speciality of the occupational doctor in primary health maintenance by the highest governmental authority on health maintenance.

2. Requesting from the medical committees in Thi Qar Governorate Council of Nasiriyah for the establishment of the occupational medical Centre to promote the optimal occupational medical care.

3. Providing of the essential medical care for the local workforces by activating of work fitness strategy through preplacement medical examination or periodic examination during employment and after injury or direct from sick leave.

Conflict of Interest: The author has no disclosures to report.

\section{Source of Funding: Self.}

Ethical Clearance: Not required.

\section{References}

1. WHO | Occupational health: A manual for primary health care workers. WHO (2010).

2. Burden of occupational diseases: OSHwiki. Available at: https://oshwiki.eu/wiki/Burden_of_occupational_ diseases. (Accessed: 21st November 2018).

3. Occupational Disease Loss Control: Risk Factors and Solutions - Aires Consulting. Available at:https://www.airesconsulting.com/occupationaldisease-loss-control-risk-factors-solutions/. (Accessed: 21st November 2018).
4. Occupational disease $\mid$ Definition, Causes, \& Facts | Britannica.com. Available at: https://www.britannica.com/science/occupationaldisease. (Accessed: 20th November 2018).

5. WHO | Occupational and work-related diseases. WHO (2012).

6. WHO $\mid$ Risk factors. WHO (2017).

7. Exposure assessment - an overview ScienceDirect Topics. Available at: ht t ps://www.sciencedirect.com/ topics/pharmacology-toxicology-and pharmaceuticalscience/exposure-assessment. (Accessed: 30th July 2018).

8. Hazard identification, risk assessment and risk control. Available at: https://www.education.vic.gov.au/school/students/ beyond/Pages/hazidentify.aspx. (Accessed: 30th July 2018).

9. Rantanen, J., Lehtinen, S., Valenti, A. \& Iavicoli, S. A global survey on occupational health services in selected international commission on occupational health $(\mathrm{ICOH})$ member countries. BMC public health 17, 787 (2017).

10. IMPACT OF WORKPLACE ENVIRONMENT ON EMPLOYEES PRODUCTIVITY.

Available at: https://www.ukessays.com/essays/ management/impact-of-workplace-environmenton-employeesproductivity-management-essay. php\#citethis. (Accessed: 18th May 2018).

11. Industrial Illnesses \& Occupational Diseases - Jefferies Solicitors. Available at: https://www.jefferies-solicitors.com/personalinjury/industrial-illnesses-and-diseases/. (Accessed: 18th May 2018).

12. NHLS. National Institute for Occupational Health _Cancer Statistics. 6528 (2000).

13. Prevention and control strategies - OSHWiki. Available at: https://oshwiki.eu/wiki/Prevention_and_control_ strategies. (Accessed: 30th July 2018).

14. Chapter 30 - Occupational Hygiene. Available at: http://www.ilocis.org/documents/chpt30e.htm. (Accessed: 30th July 2018).

15. ILO List of Occupational Diseases (revised 2010).

16. Nuwayhid, I. A. Occupational health research in developing countries: A partner for social justice. American Journal of Public Health 94, 1916-1921 

(2004)..

17. Parodi, S., Montanaro, F., Ceppi, M. \& Gennaro, V. Mortality of petroleum refinery workers. Occupational and environmental medicine 60, 3045; author reply 305-6 (2003).

18. Environmental, Health and Safety Issues in the Coated Wire and Cable Industry. 2002. / Wire \& Cable / Toxics Use Reduction for Industrial Sectors / TURI Publications / TURI - TURI Toxics Use Reduction Institute. Available at: https://www.turi.org/TURI_Publications/Toxics_ Use_Reduction_for_Industrial_Sectors/W e Cable/Environmental_Health_and_Safety_Issues_ in_the_Coated_Wire_and_Cable_Industry._2 02 . (Accessed: 19th April 2018).

19. Healy, J., Bradley, S. D., Northage, C. \& Scobbie, E. Inhalation exposure in secondary aluminium smelting. The Annals of occupational hygiene 45, 217-225 (2001).

20. Prevention and control strategies OSHWiki. Available at: https://oshwiki.eu/wiki/Prevention_and_control_ strategies. (Accessed: 17th May 2018).

21. WHO | Chapter 21: Selected occupational risk factors. WHO (2010).

22. Iraq Then and Now: A Guide to the Country and Its People - Karen Dabrowska, Geoff Hann - Google Books. Available at: h t t p s : / / b o o k s.g o o g 1 e. i q / books?id=DhJ31RnXyXcC\&pg=PA262\&redir_ esc $=\mathrm{y} \# \mathrm{v}=$ onepage $\& \mathrm{q} \& \mathrm{f}=$ false. $($ Accessed: $\quad 25$ th April 2018).

23. Dhi Qar Governorate - Wikipedia. Available at: $\quad$ https://en.wikipedia.org/wiki/Dhi_Qar_ Governorate. (Accessed: 25th April 2018).

24. Home - Central Statistical Organization. Available at: http://www.cosit.gov.iq/en/. (Accessed: 25th April 2018).
25. Great Britain. Health and Safety Executive. Health and safety at work: vital statistics 2017 : overall picture for Great Britain.

26. Sampling Method, Size and Calculation | Sampling (Statistics) | Confidence Interval. Available at: https://www.scribd.com/doc/63595988/SamplingMethod-Size-and-Calculation. (Accessed: 26th April 2018).

27. What is the Statistical Package for the Social Sciences (SPSS)? - Definition from Techopedia. Available at: https://www.techopedia.com/ definition/12401/statistical-package-for-thesocialsciences-spss. (Accessed: 21st November 2017).

28. Health Determinants. Available at: https://www. med.uottawa.ca/sim/data/Pub_Determinants_e. htm. (Accessed: 21st November 2018).

29. Sekkal, S. et al. Occupational exposure to petroleum products and respiratory health: a cross-sectional study from Algeria. Journal of occupational and environmental medicine 54, 1382-1388. (2012).

30. Feder, K. et al. Prevalence of Hazardous Occupational Noise Exposure, Hearing Loss, and Hearing Protection Usage Among a Representative Sample of Working Canadians. Journal of occupational and environmental medicine 59, 92 (2017).

31. Safety and Health Topics | Occupational Noise Exposure - Health Effects | Occupational Safety and Health Administration. Available at: h t t p s : / / w w w . o s h a.g o v / S L T C/ noisehearingconservation/healtheffects.html. (Accessed: 21st November 2018).

32. Holmstrom, M. \& Lund, V. J. Malignant melanomas of the nasal cavity after occupational exposure to formaldehyde. Occupational and Environmental Medicine 48, 9-11 (1991). 